\title{
CULTURAL CONTINUITIES AND DISCONTINUITIES AT THE NEOLITHIC TRANSITION IN EASTERN IBERIA: AN ANALYSIS OF THE MORPHOMETRY OF GEOMETRIC MICROLITHS
}

Alfredo Cortell-Nicolau ${ }^{\mathrm{a}}$, Oreto García-Puchol ${ }^{\mathrm{a}}$, Stephen Shennan ${ }^{\mathrm{b}}$

a PREMEDOC Research Group. Departament de Prehistòria, Arqueologia i Història Antiga. Universitat de València. Av. Blasco Ibáñez, 28. 46010 València. Spain.

e-mail acn (corresponding author): alfredo.cortell-nicolau@uv.es

telephone acn (corresponding author): 0034963983894

${ }^{\mathrm{b}}$ UCL Institute of Archaeology, 31-34 Gordon Square, London WC1H 0PY, UK

ORCID:

Alfredo Cortell-Nicolau: 0000-0003-1982-6403

Oreto García-Puchol: 0000-0001-9716-6039

Stephen Shennan: 0000-0001-6605-064X

\section{ABSTRACT}

The main goal of this paper is to explore possible cultural continuities and discontinuities at the Neolithic transition in Eastern Iberia. To address this issue we introduce a twofold methodology, consisting of Geometric Morphometrics and the use of the self-developed Geomeasure system, to examine evolutionary patterns in geometric microliths. These are a specific type of arrowhead shared by both the last huntergatherers and the first farmers from two reference sites in the region: Cueva de la Cocina and Cova de l'Or (Eastern Iberia). Although advances in research have contributed to a better comprehension of this process, there are still unanswered questions, especially when the study is approached from a regional perspective. Such is the case for the Neolithisation of the Eastern Iberian Peninsula, and the way in which the previous Mesolithic population interacted - if they interacted at all—with the first farmers. In this case, some sites present archaeological contexts that have been catalogued as acculturation contexts. This has traditionally been the case for phase $\mathrm{C}$ of Cueva de la Cocina (Spain), although recent research points to the possibility that the content of this specific deposit is to the result of post-depositional processes. Here we try first to understand the cultural evolutionary patterns and relations between the different geometric microlith technocomplexes and, second, to address the specific problem of the interpretation of taphonomic disturbances in the archaeological record. We use the the Cueva de l'Or and the Cueva de la Cocina for comparison, and our conclusions raise serious doubts about the existence of an acculturation phase at the latter.

Keywords

Mesolithic. Neolithic. Geometric Microliths. Geometric Morphometrics. Geomeasure 
Funding and Acknowledgements:

This research was financed by the Spanish Ministry of Economy, Industry and Competitiveness, grant HAR2015-68962-P (EVOLPAST): "Evolutionary dynamics and patterns of cultural change among the last hunter-gatherers and the early Neolithic in the Eastern Peninsula (circa 7000-4500 cal BC)", the Ministry of Science, Innovation and Universities, grant PGC2018-096943-B-C21: "CHRONOEVOL: High resolution chronology and cultural evolution in the east of the Iberian Peninsula (circa 7000-4000 cal BC): a multiscalar approach, and the Conselleria d'Educació, Cultura, Investigació i Esport de la Generalitat Valenciana, grant AICO2018-005: "Globalización vs. Fragmentación cultural. Una evaluación del papel de la demografia durante la transición neolítica (c. 6500-200 a.C.)" ACN is supported by MINECO predoctoral grant BES-2016-076578.

\section{Conflict of interest/Competing interests}

The authors hereby declare that they do not have any type of conflict of interest

Availability of data and material

The data used in this article has been provided as supplementary material 1

Code availability

The code cannot be provided at this moment, as it is being compiled for its publication as an R package, but will be made open and public shortly, as soon the R package is completed 


\section{CULTURAL CONTINUITIES AND DISCONTINUITIES AT THE NEOLITHIC TRANSITION IN EASTERN IBERIA: AN ANALYSIS OF THE MORPHOMETRY OF GEOMETRIC MICROLITHS}

\section{INTRODUCTION}

Despite, or maybe because of, the great quantity of literature and effort produced on the subject, the process of Neolithisation in the Mediterranean still raises substantial debate within the archaeological research community (Guilaine 2013; García-Puchol and Salazar García 2017). Even though the general patterns are generally understood and accepted, following the overall lines proposed by Ammermann and CavalliSforza (1984), in their now classic work, it was noted from the very first moment that the Wave of Advance could be masking specific processes, mainly at the regional level (Zvelebil 1986). Of course, at this regional/local level debates have been raging for a long time and have their own historiographic traditions. In this paper we will focus on the Eastern part of the Iberian Peninsula, where the role that Mesolithic communities developed during the process of Neolithisation remains unclear. Specifically, we will concentrate on the sites of Cueva de la Cocina and Cova de l'Or to approach how geometric microliths can be used as proxies for understanding cultural change and affiliation, and how the information that they generate can be later employed to assess a number of different problems, ranging from chronology to taphonomy. Geometric microliths are a specific type of lithic tool considered, for our chronological and geographical frame, as part of composite arrowheads (García-Puchol et al. 2014). They can be found, loosely speaking, in three main forms: trapezoids, triangles and segments (or crescents), while a fourth rectangular shape can be included from sites dated to the epicardial Neolithic phase (Fig. 1 near here).

Their main function as arrowheads remained unaltered in the Western Mediterranean from their first appearance, in the Solutrean and Magdalenian (González Sainz 1989; Aura 1995; Straus 2002) to their expansion in the Late Mesolithic and the Early Neolithic (García-Puchol and Jardón 1999; Gibaja and Palomo 2004; Domingo 2009, 2012). However, there is a clear difference as far as their shape and retouch type are concerned from the Sauveterroidean types (Plisson et al. 2008; Fontana et al. 2016) to the Castelnovian types of the Second or Late Mesolithic (Blade and Trapeze tradition), starting around 8.600 cal BP (Binder 1987; Perrin 2001; Perrin and Binder 2014; Marchand and Perrin 2017). In this sense, the Iberian Peninsula constitutes a good example of the complexity and regionalization of these evolutionary processes. This is proved not only by the Notches and Denticulates technocomplexes (Aura et al. 2006) that emerge between the regional Sauveterrian and the Late Mesolithic, but also by the changes affecting regional geometrism in which, as we will see later, subphases A and B can be distinguished within the regional Late Mesolithic mainly by the increasing presence of triangles, and the emergence of an exclusive type, known as the Cocina type triangle, and defined by the concavity of its two sides (Fortea 1973). With the Neolithic arrival these gradual changes were disrupted, and new geometric types became established. These technocomplexes are characterised by their higher retouch variability and their tendency towards straighter sides. This particular transitional period will be the main focus of this paper. A more comprehensive and complete approach to the complexity of geometrism in the Iberian Peninsula is given by Utrilla \& Montes (2009).

The geometric microliths have a unique role in understanding how cultural transmission processes evolve and/or relate to population flows not only because these lithic pieces share common traits and functional 
backgrounds but also because in this case archaeology recovers finished tools in the form that was intended and not only worn-out discards. Furthermore, because, unlike other artefact types, geometric microliths were used by both the last hunter-gatherers and the first farmers, they can be considered as a reliable proxy when trying to understand the process of Neolithisation, and how it is reflected in material culture. Therefore, their archaeological significance to studying the cultural evolutionary patterns and changes from the Late Mesolithic to the Early Neolithic can be summarised in the following points: (1) they are present both in the Late Mesolithic and the Early Neolithic records, (2) their function is considered to be the same in the two cases, and (3) they present chronological and geographical variability as far as their retouch, general shape, and the linearity of their sides is concerned. The question then becomes, is there a local lineage continuity in these types or not?

\subsection{Regional archaeological background}

There have been many debates regarding the transition to farming and husbandry in the Iberian Peninsula. Without intending to provide a complete historiographic review, we would acknowledge the main theories - once the autochthonist options were discarded - as the capillary models of Rodríguez et al. (1995) and Vicent (1997), following Lewthwaite's (1986) proposals and the mosaic models, initially developed by Barandiarán and Cava (2000). As for the theoretical proposals emphasising the demic factor in the Neolithisation of the Iberian Peninsula, one of the most accepted theories is the so-called Dual Model (DM), initially formulated by Fortea, Martí and colleagues for the region of Eastern Iberia (Fortea and Martí 1984; Fortea et al. 1987), and later refined by Bernabeu and colleagues (Bernabeu et al. 1993; Bernabeu 1996). In its most basic form, the model combines the Neolithic spread, as defined by the Wave of Advance Model (Ammerman and Cavalli-Sforza 1984), including the use of sea routes (Zilhão 1993, 2001, 2014; Bernabeu and Martí 2014), with the Iberian archaeological record. The DM considers three possible ways of Neolithic diffusion: (1) colonisation, where only demic expansion takes place, (2) direct acculturation, where agriculturalists directly interact with hunter-gatherers, thereby providing technology and promoting cultural modification, and (3) indirect acculturation, where transmission of agriculture spreads through the pre-existing Mesolithic networks. Given the lack of archaeological support for indirect acculturation in the Eastern Iberian Peninsula (the region for which the model was originally formulated), the DM concentrates on the first two options. In this respect, the model identifies colonisation with the situation seen in caves such as Cova de l'Or, or Cova de la Sarsa, where we find ex novo Neolithic sequences, without any trace of previous Mesolithic occupation. The second option, direct acculturation, corresponds to frontier situations, where we can find possible acculturation, such as the Cueva de la Cocina, with a sequence that is mainly Mesolithic, but also with Neolithic elements on top and, as we will see, possible acculturation phases.

Therefore, Cocina and Or (Fig. 2 near here) are crucial to understanding the Neolithisation process in the Eastern Iberian Peninsula. Moreover, they both contain some of the largest archaeological collections for this region and timeframe. They are also especially significant for understanding the archaeological processes underpinning Neolithisation, as just noted. In the case of Cova de l'Or, the absence of a Mesolithic sequence in the cave (Martí et al. 1977, 1980; Martí 1981, 2011) makes the site a clear example of the ex novo Neolithic. On its part, Cocina shows a long and significant sequence, primarily of the Geometric Mesolithic of Castelnovian tradition, including levels with pottery on top. Javier Fortea (Fortea 
1973) established four phases characterised by different types of arrowheads, where (broadly) Cocina I, later known as phase A (Juan-Cabanilles 1985), would belong to a blade- and trapeze-based Mesolithic, Cocina II (phase B) would stand for a Mesolithic marked by Cocina type triangles, Cocina III (phase C) would represent a process of Mesolithic-Neolithic contact, showing crescents and double bevel retouch, and Cocina IV (not in use in archaeological research any more) would stand for more advanced chronologies, including bifacial arrowheads. In order to understand the significance of this transitional phase $(\mathrm{C})$ recent studies have considered possible post-depositional disturbances (Juan-Cabanilles and Martí 2007; Pardo-Gordó et al. 2018; García-Puchol et al. 2018a) after previous taphonomic studies of the cave revealed the existence of flooding episodes (Fumanal 1978).

1.2 Main goals

This paper tries to address the same problem from a different perspective. We believe that, because the geometric microliths reflect culturally significant morphometric variation, they can be used in and of themselves in order to understand continuity, discontinuity and patterns of evolutionary change. We would expect faster evolutionary rates, including lineage discontinuity, in contexts of traumatic or demic culture substitution, whereas lower evolutionary rates would result from a process of indigenous acculturation (Edinborough et al. 2015).

Due to the fact that taphonomic studies are challenging the archaeological assumption of the so-called phase $\mathrm{C}$ at Cueva de la Cocina, here we examine the differences in cultural attribution and stylistic change of the geometric microliths to see if we can find factors that strengthen or weaken the arguments for the existence of this transitional phase. In this sense, we would expect to find consistent evolutionary trends and stylistic grouping within the geometric microliths under study during the different Late Mesolithic and Early Neolithic phases proposed, corresponding to either lineage continuity or discontinuity, whereas inconsistency could be produced by different types of archaeological palimpsests related to postdepositional processes.

In order to do so, we have applied different morphometric and statistical techniques, including the selfdeveloped Geomeasure system (GS) (see Methods sub-section) or the now well-established Geometric Morphometrics (GM) approach (Rohlf and Marcus 1993; Corti 1993) for further testing of grouping and variability. In this way, we aim to apply these methodological tools from a new perspective, using the taphonomic disturbances of Cueva de la Cocina as a case study. We also offer a brief comparison of the two methods to assess their strengths and possible complementarity. The following section presents the materials used and the filtering criteria, and then describes how exactly the methodology was developed, employing both GS and GM. The third section presents the results of both analyses. The fourth section examines their archaeological implications. Finally, some short conclusions are offered.

\section{MATERIALS AND METHODS}

\subsection{Materials}

Cueva de la Cocina, and Cova de l'Or are the main sites being considered in this study. We have already seen the archaeological significance of both for the Neolithic transition in Eastern Iberia. The former was first excavated by Lluís Pericot, in the early 1940s (Pericot 1945) and later by Javier Fortea in late 1970sno was monograph published. Currently, it has been the subject of four campaigns (2015-2018) directed by Oreto García-Puchol, Joaquim Juan-Cabanilles and Sarah B. McClure (García-Puchol et al. 2015, 2017, 
2018b). As for Cova de l'Or, the first excavation at the site was directed by Vicent Pascual during the 1950s, while Bernat Martí directed a new intervention during the 1970s and 1980s (Martí et al. 1980). For this project, we have added all of the geometric microliths recovered at Cueva de la Cocina so far-except the ones found in the EII sector of Pericot's 1945 campaign, due to the severe stratigraphic problems affecting them (Fortea 1971) — which add up to 2.140 pieces, and all of the ones recovered by Pascual at Cova de l'Or, which represent the bulk of the collection, giving a total of 146 geometrics.

However, before beginning the actual morphometric study, some methodological and theoretical issues need to be addressed. Starting with the methodological, the first problem is that the bulk of the two collections belongs to old excavations, where the resolution, both chronological and stratigraphic, was not as high as desired. To address this problem, we relied on the work done in the last few years at Cueva de la Cocina, aided by three-dimensional reconstruction (Diez-Castillo et al. 2017), which has allowed us to form high resolution phases on the basis of Bayesian inference (García-Puchol et al. 2018a). Because this work has only been deployed so far on Cocina's 1941, and 1945 EI excavations, we have only used the material from these two surveys. As for Cova de l'Or, the sample is affected by problems similar to Cocina, but we used Juan-Cabanilles' (Juan-Cabanilles 2008) comparative study of Pascual's materials for those found in Marti's excavations - much smaller in number, but referenced with high resolution stratigraphy, and $x y z$ coordinates. There he established the four Neolithic phases - Or Ia, Or Ib, Or II and Or III—-that form the basis of our study.

The second problem is related to the stylistic character of the geometric microliths. Our assumption is that their form contains a transmission signal; in other words that their form is not so entirely determined by their function that any tradition would converge on the same form, resulting in equifinality. Although there are some exceptions, pointing to multivariate use (Finlayson and Mithen 1997), most of the experimental and use-wear studies developed over the past years, conclude a mainly predominant use for the geometric microliths in the Western European Late Mesolithic and Early Neolithic as composed arrowheads (Fischer et al. 1984; García-Puchol and Jardón 1999; Domingo 2004, 2005, 2009, 2012; Gibaja and Palomo 2004; Longo and Isotta 2007; Plisson et al. 2008; Cristiani et al. 2009; Gibaja and Terradas 2012; García-Puchol et al. 2014; Goldstein and Shaffer 2017). However, some authors point out that, even if the use of the geometric microliths as arrowheads was highly prevalent, it could be combined with different uses such as cutting green wood, either in a multifunctional way or not. Domingo, for instance, states that the percentages use for working hides or green wood was never higher than $4 \%$, even for Early Neolithic periods (Domingo 2009, 2012). Another problem is that typometry does not help much in the distinction (Finlayson and Mithen 1997; Richter 2007). Sickles may indeed fall within specific morphometric ranges, but arrowheads, even though they can be more varied, can also occupy those ranges (Fig. 3 near here).

In any case, most of the characteristic marks of the use of microliths for working hides or green wood, such as gloss or abrasive fractures, can be observed by the naked eye or with magnifying glasses. Therefore, to stay on safe ground, we eliminated from our sample everything that either could be clearly identified as a sickle, presented gloss, had abrasive fractures, or had any kind of fracture in the middle part- not the edges - of its longer base. This has meant a reduction of the $8 \%$ of our sample, which is more than the maximum percentages of non-arrowhead use offered by other authors. 
After performing all of these filtering operations and accepting a reliability index (see next sub-section) of $95 \%$, we were left with a total of 336 geometrics (Table 1), of which we could use 204 for the GM analysis.

\begin{tabular}{|c|c|}
\hline Phase & Geometrics \\
\hline A1 & 44 \\
\hline A2 & 53 \\
\hline B1 & 35 \\
\hline B2 & 96 \\
\hline B3 & 11 \\
\hline C & 12 \\
\hline Or Ia & 42 \\
\hline Or Ib & 43 \\
\hline TOTAL & 336 \\
\hline
\end{tabular}

Table 1. Number of geometric microliths used per phase.

\subsection{Methods}

The first part of our approach has been based on the Geomeasure System (GS), the second on the use of Geometric Morphometrics (GM) (Rohlf and Marcus 1993; Corti 1993; Claude 2008; Mitteroecker and Gunz 2009; Buchanan and Collard 2010; Adams and Otárola-Castillo 2013; Adams et al. 2013; Bonhomme et al. 2014; Shott 2015; MacLeod 2018; Okumura and Araujo 2019; Silva-Gago et al. 2019).

Even though the initial rationale of the two systems is similar and is based on gathering different measures of each sample so that they can be compared, they differ in their purpose and their outputs. While GM can perform variability analyses per se, offering continuous multivariate outputs, and can, in a standalone mode, assess morphometric similarities between different groups of populations (Mitteroecker and Gunz 2009), their complete integration within different methods related to Evolutionary Biology - thus, Evolutionary Archaeology — is not straightforward, and usually depends on statistic workarounds (Adams et al. 2013). Conversely, GS is not aimed to develop an analysis on its own, but to speed up the data gathering process, and to provide different kinds of measures and offer diverse univariate outputs both in continuous and discrete forms. These can then be combined and used in different later analyses to be determined by the researcher. In this sense, although they can be combined with continuous measures in some cases, the architecture of phylogenetic analyses usually requires discrete-categorical values, both in terms of presence/absence or in terms of multistate characters (Wiley et al. 1991; Kitching et al. 1998; O'Brien and Lee Lyman 2003; Felsenstein 2004; Crema et al. 2014). The main difference with GM does not reside in the discretisation procedure, which ultimately depends on the data available, and for which different proposals have been made, primarily, in the biological field (Thiele 1993; Forey and Kitching 2000; Wiens 2001; Reid and Sidwell 2002). The main difference relies on the fact that, unlike GM, GS offers actual univariate values, not computed but taken directly from the piece, which, as such, can be discretised. We have used continuous measures for this work in keeping with our requirements.

Although GS is explained at length elsewhere (Cortell-Nicolau 2019), some description is necessary here. GS has been developed using the R Programming Language 3.3.3 (R Core Team 2017) and will be 
compiled into an R package once the final features under development are completed. At this point, the system relies on a vectorised image of the sample being studied to calculate different typometric variables. The sample is placed over a grid where 260 measures per piece are automatically taken. Besides, each measure is offered both in continuous form and in discrete form - the parameters to discretize each output can be controlled by the researcher. Because a great quantity of our sample presents fractures, each measure is accompanied by a reliability index indicating whether it has been extracted from a broken part of the piece, or not. This is useful since it maximises the use of our sample, using all complete measures, not just all complete samples. The most important measures taken include the classic measures, such as sides, angles, maximum length and width, etc. However, the strength of the system relies on the calculation of the L-measures. L-lines/measures are a series of lines displayed on a grid crossing the geometric from distal side to proximal side, and from vertex to base - or from shorter base to longer base, for that matter. We divide those lines into horizontal $\mathrm{N}$-lines and $\mathrm{S}$-lines and vertical E-lines and $\mathrm{W}$-lines, as shown in figure 4 (the lines Max_Width and Max_Length divide the domains of N-lines/S-lines and E-lines/W-lines respectively). The programme automatically captures how much of each line is crossing the geometric, providing its length as an output. Although different grids with different resolutions have been prepared, in this case we use a resolution of $1 \mathrm{~mm}$. That is, the distance between each L-line is $1 \mathrm{~mm}$. Because for the proximal-distal lines (E-W Lines) measuring the total length could mask differences in the sides and laterality, currently the measurement process is able to treat each side separately. (Fig. 4 near here).

The system can also capture the perimeter measures, and the vertex of the piece, and offer them as discrete values, as well as offering a reliability index of the overall completeness of the piece, where the value $100 \%$ would mean that the piece is complete. Only pieces with a reliability index higher than $95 \%$ were accepted fort this study.

As regards the GM approach, the past decade has seen a notable increase in its use for measuring cultural and biological variability, not only in the field of Evolutionary Biology but also in Evolutionary Archaeology (Buchanan and Collard 2010; Thulman 2012; Buchanan et al. 2014; Ragan and Buchanan 2018). This increase has also led to a refinement of its methods, and a development of affordable tools and packages (Adams and Otárola-Castillo 2013). GM can be approached in two different ways, not necessarily exclusive, and often complementary; based on different types of landmarks, or on the actual outline of the shape (Claude 2008). In our case, we have done preliminary analysis both with landmarks, using the geomorph R Package (Adams and Otárola-Castillo 2013) and outlines, using the momocs R package (Bonhomme et al. 2014). In this work, we will follow an outline analysis, which can bring different insights and high accuracy using the data extracted from GS.

For GM outline analysis to work properly there are some conditions applicable to the sample under study. Pieces need to be complete - this is not necessary using landmarks, where missing landmarks can be inferred - and must also be scaled and centred following a General Procrustes Alignment (GPA) which fits the units to the same centre and spatial dimensions (Claude 2008). This is another difference from GS, where all of the information is gathered based on a 1:1 scale, not following GPA. While it is necessary for the piece to be compared under GM techniques, this scaling of the sample may not be necessarily wanted by the researcher if size, regardless of shape, does matter to infer cultural differences. Although it is true that some solutions for estimating size have been provided, they are often comprised of complementing 
GM methods, not on GM themselves (Piras et al. 2010; Okumura and Araujo 2019). Methods to estimate allometry have indeed been effectively developed (Adams et al. 2013). However, allometry refers not only to the variation in size, but to the effects that growth - reduction, in the case of lithics - has on size variation, and how shape and size covary through time (Claude 2008; Klingenberg 2016). The implications and differences of each idea, via lithic reduction/lithic conception can be significant (Dibble 1984, 1987; Barton 1990, 1991; Blades 2003; Clark and Barton 2017; Cortell-Nicolau et al. 2019).

Because the outline design relies on the pixel contrast, methods exist to treat images extracting that contrast (Claude 2008). In our case, and because our images were already vectorised, that task has been a relatively fast process, since we have included a function within the GS environment to produce .jpg outputs, suited for GM analysis (Fig. 5 near here).

Once the outlines are correctly introduced into the software, a Fourier analysis is performed. Fourier analysis is based on Fourier transformation series and captures the sine wave produced by the shape of the piece, at $n$ harmonics, to be specified by the researcher. In our case, we used an elliptical Fourier analysis, at 20 harmonics, to pass the data to further statistical analyses; this has been advised for complex routines, over different Fourier methods (Rohlf and Archie 1984).

Once each sample was processed, we applied different statistical procedures for each method, often common, but sometimes slightly adapted. For GS, we developed Principal Component Analyses (PCA) on different groups of measures. This not only gave us an idea of variation, but it also offered new variables accounting for significant amounts of variance, thus reducing the number of dimensions in our data frame and preparing all of the information for further analysis. The next step was to create a data frame, where means of different measures, grouped by phases, were paired to the mean results of principal components one and two of N-Lines, S-Lines, E-Lines and W-Lines. From these data, the Jaccard distance by phases was calculated and clustered.

As for GM, we have also applied PCA. However, it has been argued that PCAs can obscure the meaning of between group separations in relation to within group separations (MacLeod 2018). For this reason MacLeod recommends the use of Linear Discriminant Analysis (LDA), which we also applied. Indeed, on comparing, we observed that LDA offers a neater separation between groups, and that it does not always coincide with PCA results. PCA is not designed to capture variation between groups, but rather to find out which are the elements, or eigenvectors, accounting for the major amount of variance, thus offering a way to reduce the dimensionality of the data. This makes PCA useful for GS $(d=260)$, but might require complementary analyses under a GM perspective. The LDAs produced by the GM analysis were also crossvalidated to obtain the mispredictions of the analysis, therefore gaining new knowledge on where the potential conflicts exist. We also used K-means clustering $(c=5)$ to obtain morphometric clusters, regardless of the phase, so that we could assess the main vectors defining the morphometry of the sample. Finally, and in order to test between group similarity, we ran a pairwise MANOVA analysis, aimed at refining the information obtained from the different clusters.

\section{RESULTS}

The first PCAs obtained from the GS data have been divided into four groups, as shown in fig. 6 for visualisation. They are divided on the basis of the correlated variables to observe how do these groups relate 
to one another, which eigenvectors are accounting for maximum variance, and what features are responsible for this variance and to what extent (Fig. 6 near here).

Fig. 6a shows that PC1 and PC2 account for $80.4 \%$ of the variance, with the variables Width and Length pulling significantly in different directions, thus showing independence between width and length. However, the variable Area falling in the middle of both, hints at correlation among them—on the other hand, expected. We have decided to put them together in the similarity analysis as Ratio 1 (R1), defined by Length/Width, as R1 could be indicative of the relationship between Length, Width and Area. On the other hand, Length seems to affect especially the distribution of phase $C$, while Width seems to be especially relevant for Neolithic phases. In Fig. 6b, PC1 and PC2 account for $80.2 \%$ of the variance, where again we can see that width (L-Width) affects the Neolithic phases more significantly, while Length (L-Length) seems to be a stronger determinant for Mesolithic phases. This seems somehow symmetrical to how the proximal angle (Angle 1) and the distal angle (Angle 2) affect the different phases, perhaps hinting to some changes in laterality, to be further studied. In Fig. 6c, 98.2\% of the variance is explained by PCs 1 and 2 , thereby achieving a significant dimensionality reduction of L-Lines. The behaviour of NS-Lines, and WELines, grouping together, could be indicating a high degree of overall symmetry on the component measurement of the geometrics, although we can see a stronger distinction between the Neolithic eigenvalues, in relation to the phase B Mesolithic values. This does not contradict possible changes in laterality from one phase to another. In the last PCA, PC1 and PC2 account for $91.1 \%$ of the variance. We separately analysed the L-lines for each side on the basal part and the vertex of each geometric. The results observed in the first analysis (6a) reappear, when we see how proximal measures cluster together, affecting the Neolithic sample, while distal measures seem to have more influence on the results of the Mesolithic. Again, possibly pointing to changes in the laterality. An overview of these four analyses combined hints at a relationship between the different groups. We can, indeed, see how sub-phases are clustered together within their major phase, and Neolithic geometrics tend to group further away from the Mesolithic samples, which was expected. However, what was not expected was Mesolithic phase A clusters being closer to the Neolithic sample than to the Mesolithic phase B. Finally, Mesolithic phase B and Mesolithic phase C seem to group together, which relates phase $\mathrm{C}$ (supposedly transitional) to the Late Mesolithic.

In view of these results, we decided to perform a preliminary exploration of the anomaly where the Mesolithic phase A is closer to the Neolithic than it is to its next chronological stage. We did this by applying a Jaccard similarity analysis, based on the data mentioned at the previous section. Fig. 7 (Fig. 7 near here) shows that such relationships are confirmed by the Jaccard similarity analysis. Clusters are divided between the phase A and the Neolithic, and the phases B and C (7a). The dissimilarity values reach their maximum when phases B and C (mainly C) are compared to the Neolithic. This situation is to be explored in further research.

As for the GM analysis, the results of the PCA, where PC1 and PC2 account for an $84.6 \%$ of the variance are, as expected, similar to the ones obtained with GS regarding the grouping of the different phases. Phase $\mathrm{C}$ does not show relationship with the Neolithic sample (Fig. 8 near here).

However, when performing the LDA we can observe significant changes, where phase $\mathrm{C}$ has dramatically changed its position, and relocated entirely within the Neolithic phases. Interestingly, no matter the 
analysis, phase A remains more correlated to the Early Neolithic sample than phase B, inconsistent with a process of linear change (Fig. 9 near here).

Nevertheless, this LDA analysis must be considered with care for two main reasons. First, the LD1 and LD2 only account for $52.3 \%$ of the variance, while the cross-validation test only reaches an average of $28.4 \%$ correctly classified samples. In fact, after $n=25$ iterations of CV tests on LDA inputs, we can observe in Fig. 10 how the geometrics of phase $\mathrm{C}$ have been mispredicted $100 \%$ of the time, of which $71.43 \%$ have been classified as Neolithic samples (Fig. 10 near here).

As for the K-means, adjusted at 5 classes, the value of the sum of squared distances of each class mean to the global mean accounts for $75.6 \%$ of the total sum of squared distances of each point to the global mean. This shows that there are discernible patterns of clustering based on the morphometry of the pieces, where concavities, laterality and width of the geometrics seem to be especially relevant for grouping (Fig. 11 near here).

Finally, the results of the pairwise MANOVA analysis (Table 2) do bring new information on the trends previously hinted at. On the one hand, and as expected, we can accept $H_{0}$ - there is no difference between populations — when subphases are paired (A1 A2: $V=0.19, p$-value $=0.11 / \mathrm{B} 1 \sim \mathrm{B} 2: V=0.03, p$-value $=0.92 / \mathrm{B} 1 \sim \mathrm{B} 3: V=0.41, p$-value $=0.14 / \mathrm{B} 2 \sim \mathrm{B} 3: V=0.18, p$-value $=0.11 /$ Or Ia $\sim$ Or Ib: $V=0.14, p$ value $=0.4$ ). On the other hand, some difference between phase A2 and phase B could be accepted, even though the values are at the limit of acceptance $(\mathrm{A} 2 \sim \mathrm{B} 1: V=0.25, p$-value $=0.06 / \mathrm{A} 2 \sim \mathrm{B} 3: V=0.27, p$ value $=0.13$ ). Paradoxically, phase B3, which already showed some problems on the previous LDA analysis, is the only one not significantly different from phase $\mathrm{C}(\mathrm{B} 3 \sim \mathrm{C}: V=0.58, p$-value $=0.21)$, again contradicting the results of LDAs, where phase C seemed to be more correlated to Neolithic phases.

\begin{tabular}{|l|r|r|r|r|r|r|}
\hline Phases & Df & \multicolumn{1}{|l|}{ Pillai } & approx F & num Df & den Df & Pr(>F) \\
\hline A1 - A2 & 1 & 0.19644424 & 1.7811292 & 7 & 51 & 0.11146706 \\
\hline A1 - B1 & 1 & 0.33089653 & 2.61398217 & 7 & 37 & 0.02682149 \\
\hline A1 - B2 & 1 & 0.25305787 & 3.62991209 & 7 & 75 & 0.00201078 \\
\hline A1 - B3 & 1 & 0.55130148 & 4.38809972 & 7 & 25 & 0.00269494 \\
\hline A1 - C & 1 & 0.71119465 & 9.85015886 & 7 & 28 & $3.79 \mathrm{E}-06$ \\
\hline A1 - Or Ia & 1 & 0.62746098 & 10.8275308 & 7 & 45 & $6.50 \mathrm{E}-08$ \\
\hline A1 - Or Ib & 1 & 0.43968761 & 4.82041482 & 7 & 43 & 0.00045199 \\
\hline A2 - B1 & 1 & 0.25371316 & 2.13693765 & 7 & 44 & 0.05920908 \\
\hline A2 - B2 & 1 & 0.15879035 & 2.211239 & 7 & 82 & 0.0414651 \\
\hline A2 - B3 & 1 & 0.27755687 & 1.75630628 & 7 & 32 & 0.1310892 \\
\hline A2 - C & 1 & 0.70265966 & 11.815747 & 7 & 35 & $1.30 \mathrm{E}-07$ \\
\hline A2 - Or Ia & 1 & 0.62962254 & 12.6281877 & 7 & 52 & $2.47 \mathrm{E}-09$ \\
\hline A2 - Or Ib & 1 & 0.4492877 & 5.82735812 & 7 & 50 & $5.65 \mathrm{E}-05$ \\
\hline B1 - B2 & 1 & 0.03613707 & 0.36420723 & 7 & 68 & 0.91988754 \\
\hline B1 - B3 & 1 & 0.41338027 & 1.81203903 & 7 & 18 & 0.14637948 \\
\hline B1 - C & 1 & 0.71067494 & 7.36896005 & 7 & 21 & 0.00016199 \\
\hline B1 - Or Ia & 1 & 0.81231778 & 23.4956997 & 7 & 38 & $5.65 \mathrm{E}-12$ \\
\hline B1 - Or Ib & 1 & 0.76244367 & 16.5061437 & 7 & 36 & $1.60 \mathrm{E}-09$ \\
\hline B2 - B3 & 1 & 0.18049261 & 1.76196203 & 7 & 56 & 0.11340564 \\
\hline
\end{tabular}




\begin{tabular}{|l|r|r|r|r|r|r|} 
B2 - C & 1 & 0.55646334 & 10.5745283 & 7 & 59 & $1.56 \mathrm{E}-08$ \\
\hline B2 - Or Ia & 1 & 0.77075226 & 36.5027263 & 7 & 76 & $7.83 \mathrm{E}-22$ \\
\hline B2 - Or Ib & 1 & 0.6220162 & 17.3965121 & 7 & 74 & $2.08 \mathrm{E}-13$ \\
\hline B3 - C & 1 & 0.57781304 & 1.75965283 & 7 & 9 & 0.21109806 \\
\hline B3 - Or Ia & 1 & 0.70424268 & 8.84427316 & 7 & 26 & $1.49 \mathrm{E}-05$ \\
\hline B3 - Or Ib & 1 & 0.61734423 & 5.53136506 & 7 & 24 & 0.00069979 \\
\hline C - Or Ia & 1 & 0.59449527 & 6.07368731 & 7 & 29 & 0.00020138 \\
\hline C - Or Ib & 1 & 0.56018659 & 4.91280992 & 7 & 27 & 0.00112118 \\
\hline Or Ia - Or Ib & 1 & 0.1460467 & 1.07500943 & 7 & 44 & 0.39536739 \\
\hline
\end{tabular}

Table 2. Results of the MANOVA analysis for population similarities between each phase.

\section{DISCUSSION}

In this paper we have introduced new statistical procedures applied to geometric microliths in order to test hypotheses of cultural evolutionary patterns within the Neolithic transition in Eastern Iberia. To do this we used GM and GS methods to explore cultural evolution patterns in terms of continuity or breakdown, trying to connect them with the current explanation of two main sites that encompass Last Mesolithic and Early Neolithic sequences in Eastern Iberia. In particular we have tried to see if the transitional phase proposed by some authors in Cueva de la Cocina has an actual archaeological meaning, or if it corresponds to a palimpsest created by the post-depositional processes affecting the cave. In order to support the archaeological significance of phase $\mathrm{C}$, it would be expected for it to show consistent correlations with the other phases ( $\mathrm{A}$ and $\mathrm{B}$ at the site), or at least a somehow equivalent position between phases during the different analysis performed. However, this is not the case. Contrary to the other phases, which, as expected, show similar results throughout the different tests, phase $\mathrm{C}$ does not show a consistent position through the different tests performed, grouping with different phases depending on the factors analysed. This leads us to think that the way in which phase $\mathrm{C}$ was formed may have its origin in disturbances that have affected the upper layers of the cave. If this was so, as our results seem to substantiate, then we could not speak of the phase $\mathrm{C}$ of Cueva de la Cocina as an acculturation phase, but rather as a previously unrecognised palimpsest.

We would also like to refer briefly to the relationship between phase A and the Early Neolithic. When taken separately, the behaviour of phase A could be accepted as drifting towards phase B, which seems to be interrupted in the Early Neolithic (Fig. 12 near here). Nevertheless, the different analyses performed show a higher A $\sim$ Or I correlation than A $\sim \mathrm{B}$ correlation, even though there is a significant chronological gap between them. This relationship, although unexpected, is consistent through all the analyses.

Although this was not the objective of the article, and therefore needs further research, we believe that some short comments are due. The recent increase in ancient DNA analyses and paleogenomics allows us to better understand processes of genetic continuity and introgression of Mesolithic genes into the genomes characteristic of Early Neolithic colonists (Vidal Encinas et al. 2008; Haile et al. 2009; Edwards et al. 2011; Hernández 2015; Irving-Pease et al. 2018; Ollivier et al. 2018). As a matter of fact, genomic studies on European Mesolithic and Neolithic populations, particularly at the site of La Mina (Cataluña, Spain), show an increase of up to $20 \%$ Mesolithic 'Western Hunter Gatherer' (WHG) genomic admixture no less than 
1500 years after the Neolithic spread in the Peninsula (Shennan 2018). They also confirm the survival of hunter-gatherer ancestry well into the Middle Neolithic (Olalde et al. 2019). This shows that phylogenetic traces of ancestry, and the populations bearing those traces, can continue at different scales long after they have become a minority. Whether this is applicable to cultural transmission and evolution is a path worth exploring. On the other hand, homoplasies are well known in ecological and archaeological literature (Wiley et al. 1991; O'Brien and Lee Lyman 2003; O'Brien et al. 2014), albeit less likely in the case of traits with a very strong transmission signal. Lastly, we can consider the possibility of an initial common drift for the Mesolithic A Iberian groups and the Neolithic newcomers, that would be two groups of population coming from the same origin but evolving differently. In this sense, recent studies on the Castelnovian spread (Perrin et al. 2010; Perrin and Binder 2014; Marchand and Perrin 2017) or on the lithic industry belonging to the Impressa culture (Manen et al. 2019) should bring significant information.

\section{CONCLUSION}

In this paper we have focused on the study of temporal morphological variability in geometric microliths, and how we can use it to address different research questions. In doing so we have used, as case study, two main sites, one of which (Cueva de la Cocina) has been argued to represent the development of a possible acculturation process (represented by Cocina $\mathrm{C}$ from Fortea's interpretation) of the last hunter-gatherers, and the other (Cova de l'Or) showing an ex novo Neolithic context, without a Mesolithic presence. Our results, showing the lack of coherence in the morphometric variation of the Cocina phase $\mathrm{C}$ sample would reinforce the idea of percolations and taphonomic problems indicated in previous works that have addressed the hypothesis of a Mesolithic acculturation at the site (Pardo-Gordó et al. 2018; García-Puchol et al. 2018a).

As regards the apparent similarity between the geometrics of Mesolithic phase A and the Neolithic, more research is needed in order to clarify its meaning. There are three possibilities: cultural resilience, convergence, or common origin, but we are aware that they need further study in order to evaluate its actual significance.

We have also seen two different approaches to the morphometric study of cultural variation, and how it can be applied to different research questions. One (GS) is designed to obtain specific univariate continuous/discrete measures in order to perform further studies. The other (GM) is a comprehensive method, based on continuous multivariate measures, with a well-developed and increasing theoretical and methodological framework, able to obtain specific results on a standalone basis. As is usually the case with theoretical and methodological tools, the use of one, the other, or both will depend mainly on the fundamental questions to be answered by the researcher.

Finally, this present paper provides a first approach to the typometric evolution of the geometric microliths of the Late Mesolithic and the Early Neolithic in the Eastern Iberian Peninsula on the basis of GM and GS methods. Morphometry is not the only factor to be accounted for when studying stylistic trends (Shott 2015), but it is obviously an important one (Buchanan and Collard 2010). More work is on the way in order to refine present parameters, assumptions and methodology, and also to include new variables and sources of information. In any case, we believe we have introduced some questions whose significance is worth exploring. 
References:

Adams DC, Otárola-Castillo E (2013) Geomorph: An R package for the collection and data analysis of geometric morphometric shape data. Methods in Ecology and Evolution 4:393-399. https://doi.org/10.1111/2041-210X.12035

Adams DC, Rohlf FJ, Slice DE (2013) A field comes of age: geometric morphometrics in the 21st century. Hystrix It J Mamm 24:7-14. https://doi.org/10.4404/hystrix-24.1-6283

Ammerman AJ, Cavalli-Sforza LL (1984) The Neolithic Transition and the Genetics of Populations in Europe. Princeton University Press, New Jersey

Aura E (1995) El Magdaleniense Mediterráneo: La Cova del Parpalló. Servicio de Investigación Prehistórica. Diputación Provincial de Valencia, Valencia

Aura E, Carrión Marco Y, García-Puchol O, et al (2006) Epipaleolítico-Mesolítico en las comarcas centrales valencianas. In: Alday Ruiz A (ed) El Mesolítico de muescas y denticulados en la cuenca del Ebro y el litoral mediterráneo peninsular. Vitoria-Gasteiz, pp 65-120

Barandiarán I, Cava Almuzara A (2000) A propósito de unas fechas del Bajo Aragón: Reflexiones sobre el Mesolítico y el Neolítico en la Cuenca del Ebro. Spal Revista de Prehistoria y Arqueología de la Universidad de Sevilla 9:293-326. http://dx.doi.org/10.12795/spal.2000.i9.16

Barton CM (1990) Beyond Style and Function: A View from the Middle Paleolithic. American Anthropologist 92:57-72. https://doi.org/10.1525/aa.1990.92.1.02a00040

Barton CM (1991) Retouched Tools, Fact of Fiction? Paradigms for Interpreting Paleolithic Chipped Stone. In: Clark GA (ed) Perspectives on the Past. Theoretical Biases in Mediterranean Hunter-Gatherer Research. University of Pennsylvania Press, Philadelphia, pp 143-163

Bernabeu J (1996) Indigenismo y migracionismo. Aspectos de la neolitización en la fachada oriental de la Península Ibérica. Trabajos de Prehistoria 53:37-54

Bernabeu J, Aura Tortosa E, Badal García E (1993) Al Oeste del Edén: Las primeras sociedades agrícolas en la Europa mediterránea. Síntesis, Madrid

Bernabeu J, Martí B (2014) The first agricultural groups in the Iberian Peninsula. In: Manen C, Perrin T, Guilaine $\mathrm{J}$ (eds) La transition néolithique en Méditerranée. Actes du colloque Transitions en Méditerranée, ou comment des chasseurs devinrent agriculteurs, Muséum de Toulouse, 14-15 avril 2011. Éditions Errance / Archives d’Écologie Préhistorique, Paris, pp 419-438

Binder D (1987) Le Néolithique ancien provençal Typologie et technologie des outillages lithiques. Éditions du CNRS, Paris

Blades BS (2003) End Scraper Reduction and Hunter-Gatherer Mobility. American Antiquity 68:141-156. https://doi.org/10.2307/3557037

Bonhomme V, Picq S, Gaucherel C, Claude J (2014) Momocs: Outline Analysis Using R. Journal of Statistical Software 56:1-24

Buchanan B, Collard M (2010) A geometric morphometrics-based assessment of blade shape differences among Paleoindian projectile point types from western North America. Journal of Archaeological Science 37:350-359. https://doi.org/10.1016/j.jas.2009.09.047

Buchanan B, O’Brien MJ, Collard M (2014) Continent-wide or region-specific? A geometric morphometrics-based assessment of variation in Clovis point shape. Archaeol Anthropol Sci 6:145-162. https://doi.org/10.1007/s12520-013-0168-x

Clark GA, Barton CM (2017) Lithics, landscapes \& la Longue-durée - Curation \& expediency as expressions of forager mobility. Quaternary International 450:137-149. https://doi.org/10.1016/j.quaint.2016.08.002 
Claude J (2008) Morphometrics with R. Springer-Verlag, New York

Cortell-Nicolau A (2019) Geomeasure: GIS and Scripting for Measuring Morphometric Variability. Lithic Technology 44:153-165. https://doi.org/10.1080/01977261.2019.1615805

Cortell-Nicolau A, García-Puchol O, Barton CM, et al (2019) Wandering through the Mesolithic. An archaeostatistical approach to explore the mobility patterns in eastern Iberia. Journal of Archaeological Science: Reports 26:101892. https://doi.org/10.1016/j.jasrep.2019.101892

Corti M (1993) Geometric morphometrics: An extension of the revolution. Trends in Ecology \& Evolution 8:302-303. https://doi.org/10.1016/0169-5347(93)90261-M

Crema ER, Kerig T, Shennan S (2014) Culture, space, and metapopulation: a simulation-based study for evaluating signals of blending and branching. Journal of Archaeological Science 43:289-298. https://doi.org/10.1016/j.jas.2014.01.002

Cristiani E, Pedrotti A, Gialanella S (2009) Tradition and innovation between the Mesolithic and early Neolithic in the Adige Valley (northeast Italy). New data from a functional analysis of trapezes from the Gaban rock-shelter. Documenta Praehistorica 36:191-205. https://doi.org/10.4312/dp.36.12

Dibble HL (1984) Interpreting typological variation of middle paleolithic scrapers: function, style of sequence of reduction. Journal of Field Archaeology 11:431-436

Dibble HL (1987) The Interpretation of Middle Paleolithic Scraper Morphology. American Antiquity 52:109-117. https://doi.org/10.2307/281062

Diez-Castillo A, Cortell-Nicolau A, García-Puchol O, Escribá Ruiz P (2017) Entorno 3D para el análisis y la recreación virtual de las actuaciones arqueológicas en Cueva de la Cocina (Dos Aguas, Valencia, España). Virtual Archaeology Review 8:75-83. https://doi.org/10.4995/var.2017.7028

Domingo R (2009) Caracterización funcional de los microlitos geométricos. El caso del valle del Ebro. In: Utrilla Miranda P, Montes Ramírez L (eds) El Mesolítico Geométrico en la Península Ibérica. Universidad de Zaragoza, Zaragoza, pp 357-389

Domingo R (2012) Usos de los geométricos en el Neolítico del Valle del Ebro. Rubricatum: revista del Museu de Gavà 5:137-143

Domingo R (2004) La funcionalidad de los microlitos geométricos en yacimientos del Bajo Aragón: los casos de Botiqueria dels Moros y Secans (Mazaleón, Teruel) y Costalena (Maella, Zaragoza). Saldvie 4:41-83

Domingo R (2005) La funcionalidad de los microlitos geométricos: bases experimentales para su estudio. Universidad de Zaragoza. Departamento de Ciencias de la Antigüedad, Zaragoza

Edinborough K, Crema ER, Kerig T, Shennan S (2015) An ABC of lithic arrowheads: A case study from southeastern France. In: Brink K, Hydén S, Jennbert K, et al. (eds) Neolithic diversities: Perspectives from a conference in Lund, Sweden. Acta Archaeologica Ludensia, Lund, pp 213224

Edwards CJ, Suchard MA, Lemey P, et al (2011) Ancient Hybridization and an Irish Origin for the Modern Polar Bear Matriline. Curr Biol 21:1251-1258. https://doi.org/10.1016/j.cub.2011.05.058

Felsenstein J (2004) Inferring Phylogenies. Sinauer Associates, Inc., Sunderland (MA)

Finlayson B, Mithen S (1997) The Microwear and Morphology of Microliths from Gleann Mor. In: Knecht H (ed) Projectile Technology. Springer Science-Business Media, LLC, New York, pp 107-131

Fischer A, Hansen PV, Rasmussen P (1984) Macro and Micro Wear Traces on Lithic Projectile Points. Experimental Results and Prehistoric Examples. Journal of Danish Archaeology 3:19-46 
Fontana F, Flor E, Duches R (2016) Technological continuity and discontinuity in the Romagnano Loc III rock shelter (NE Italy) Mesolithic series. Quaternary International 423:252-265. https://doi.org/10.1016/j.quaint.2015.10.046

Forey PL, Kitching IJ (2000) Experiments in coding multistate characters. In: Scotland R, Pennington RT (eds) Homology and Systematics. Coding characters for phylogenetic analysis. Taylor \& Francis, London-New York, pp 54-80

Fortea J (1973) Los complejos microlaminares y geométricos del Epipaleolítico mediterráneo español. Universidad de Salamanca

Fortea J, Martí B (1984) Consideraciones sobre los inicios del Neolítico en el Mediterráneo español. Zephyrvs 37:

Fortea J (1971) La Cueva de la Cocina. Ensayo de cronología del Epipaleolítico (Facies Geométricas). Servicio de Investigación Prehistórica del Museo de Prehistoria de Valencia. Diputación de Valencia., Valencia

Fortea J, Martí B, Fumanal P, et al (1987) Epipaleolítico y neolitización en la zona oriental de la Península Ibérica. In: Courtin J, Guilaine J, Roudil J-L, Vernet J-L (eds) Premières communautés paysannes en Méditerranée occidentale : Actes du Colloque International du CNRS (Montpellier, 26-29 avril 1983). CNRS Éditions, Paris, pp 581-591

Fumanal P (1978) Estudio sedimentológico de la Cueva de la Cocina, Dos Aguas (Valencia). Saitabi: revista de la Facultat de Geografia i Història 161-180

García-Puchol O, Diez-Castillo A, McClure SB, et al (2017) Cueva de la Cocina (Dos Aguas, Valencia) 2016: Intervención, metodología, resultados. SAGVNTVM Papeles del Laboratorio de Arqueología de Valencia 48:191-195. https://doi.org/10.7203/SAGVNTVM.48.9203

García-Puchol O, Jardón P (1999) La utilización de los elementos geométricos de la Covacha de Llatas (Andilla, Valencia). Recerques del Museu d'Alcoi 8:75-87

García-Puchol O, Mazzucco N, Gibaja JF, Juan-Cabanilles J (2014) Use-Wear Analysis of a Set of Geometric Projectils from the Mesolithic Context of Cocina Cave (Eastern Spain). In: Marreiros J, Bicho N, Gibaja J (eds) International Conference of Use-Wear. Cambridge Scholar Publishing, Cambridge, pp 213-224

García-Puchol O, McClure SB, Juan-Cabanilles J, et al (2018a) Cocina Cave revisited: Bayesian radiocarbon chronology for the last hunter-gatherers and first farmers in Eastern Iberia. Quaternary International 472B:259-271. https://doi.org/10.1016/j.quaint.2016.10.037

García-Puchol O, McClure SB, Juan-Cabanilles J, et al (2015) Avance de resultados de los nuevos trabajos arqueológicos en Cueva de la Cocina (Dos Aguas, Valencia). Campaña de 2015. SAGVNTVM Papeles del Laboratorio de Arqueología de Valencia 47:251-255. https://doi.org/10.7203/SAGVNTVM.47.7195

García-Puchol O, Pardo-Gordó S, Diez-Castillo A, et al (2018b) Actuación arqueológica en los depósitos mesolíticos de Cueva de la Cocina (Dos Aguas, Valencia): valoración preliminar. SAGVNTVM Papeles del Laboratorio de Arqueología de Valencia 50:249-254. https://doi.org/10.7203/SAGVNTVM.50.13273

García-Puchol O, Salazar García DC (eds) (2017) Times of Neolithic Transition along the Western Mediterranean. Springer International Publishing

Gibaja JF, Terradas X (2012) Tools for production, goods for reproduction. The function of knapped stone tools at the Neolitich necropolis of Can Gambus-1 (Sabadell, Spain). Comptes Rendus Palevol 11:463-472. https://doi.org/10.1016/j.crpv.2012.05.002

Gibaja JF, Palomo A (2004) Geométricos usados como proyectiles. Implicaciones económicas, sociales e 
ideológicas en sociedades neolíticas del VI-IV milenio CAL BC en el Noroeste de la Península Ibérica. Trabajos de Prehistoria 61:81-97

Goldstein ST, Shaffer CM (2017) Experimental and archaeological investigations of backed microlith function among Mid-to-Late Holocene herders in southwestern Kenya. Archaeological and Anthropological Sciences 9:1767-1788. https://doi.org/10.1007/s12520-016-0329-9

González Sainz C (1989) El Magdaleniense Superior-Final de la región cantábrica. Ed. Universidad de Cantabria, Santander

Guilaine J (2013) The Neolithic transition in Europe: Some comments on gaps, contacts, arrythmic model, genetics. In: Starnini E (ed) Unconformist Archaeology, Papers in honour of Paolo Biagi. Archaeopress, Oxford

Haile J, Froese DG, MacPhee RDE, et al (2009) Ancient DNA reveals late survival of mammoth and horse in interior Alaska. PNAS 106:22352-22357. https://doi.org/10.1073/pnas.0912510106

Hernández HH (2015) ¿Reemplazo demográfico en el Neolítico europeo? El punto de vista de la Genética. Estudios de Cuaternario 5:111-140. http://hdl.handle.net/10810/15307

Irving-Pease EK, Ryan H, Jamieson A, et al (2018) Paleogenomics of Animal Domestication. In: Lindqvist C, Rajora OP (eds) Paleogenomics: Genome-Scale Analysis of Ancient DNA. Springer, Basel

Juan-Cabanilles J (1985) El complejo epipaleolítico geométrico (Facies cocina) y sus relaciones con el Neolítico antiguo. Sagvntvm 19:9-30. https://doi.org/10.7203/SAGVNTVM.19.5309

Juan-Cabanilles J (2008) El utillaje de piedra tallada en la Prehistoria reciente valenciana: Aspectos tipológicos, estilísticos y evolutivos. Servicio de Investigación Prehistórica, Valencia

Juan-Cabanilles J, Martí B (2007) La fase C del Epipaleolítico reciente: Lugar de encuentro o línea divisoria. Reflexiones en torno a la neolitización en la fachada mediterránea peninsular. Veleia $611-628$

Kitching IJ, Forey PL, Humphries CJ, Williams DM (1998) Cladistics. The theory and practice of parsimony analysis. Oxford University Press, New York

Klingenberg CP (2016) Size, shape, and form: concepts of allometry in geometric morphometrics. Dev Genes Evol 226:113-137. https://doi.org/10.1007/s00427-016-0539-2

Lewthwaite J (1986) The transition to food production: a Mediterranean perspective. In: Zvelebil M (ed) Hunters in Transition. Mesolithic societies of temperate Eurasia and their transition to farming. Cambridge University Press, Melbourne, pp 53-67

Longo L, Isotta CL (2007) Trapezi simmetrici concavi: ricostruzione tecnologica e ipotesi di utilizzo dei complessi del Neolitico antico. Rivista di Scienze Preistoriche LVII:103-112

MacLeod N (2018) The quantitative assessment of archaeological artifact groups: Beyond geometric morphometrics. Quaternary Science 201:319-348. https://doi.org/10.1016/j.quascirev.2018.08.024

Manen C, Perrin T, Raux A, et al (2019) Le sommet de l'iceberg ? Colonisation pionnière et néolithisation de la France méditerranéenne. Bulletin de la Société préhistorique française 116:317-361

Marchand G, Perrin T (2017) Why this revolution? Explaining the major technical shift in Southwestern Europe during the 7th millenium cal. BC. Quaternary International 428:73-85. https://doi.org/10.1016/j.quaint.2015.07.059

Martí B (1981) Cova de l’Or (Beniarrés, Alicante). Servicio de Investigación Prehistórica. Diputación Provincial, Valencia 
Martí B (2011) La Cova de l’Or (Beniarrés, Alicante). SAGVNTVM Extra 12:183-186

Martí B, Pardo Ballester R, Segura Martí JM (1977) Cova de l'Or (Beniarrés-Alicante). Servicio de Investigación Prehistórica del Museo de Prehistoria de Valencia. Diputación de Valencia., Valencia

Martí B, Pascual Pérez V, Gallart Martí MD, et al (1980) Cova de l’Or (Beniarrés-Alicante). Servicio de Investigación Prehistórica del Museo de Prehistoria de Valencia. Diputación de Valencia, Valencia

Mitteroecker P, Gunz P (2009) Advances in Geometric Morphometrics. Evol Biol 36:235-247. https://doi.org/10.1007/s11692-009-9055-X

O’Brien MJ, Boulanger MT, Buchanan B, et al (2014) Innovation and cultural transmission in the American Paleolithic: Phylogenetic analysis of eastern Paleoindian projectile-point classes. Journal of Anthropological Archaeology 34:100-119. https://doi.org/10.1016/j.jaa.2014.03.001

O’Brien MJ, Lee Lyman R (2003) Cladistics and Archaeology. University of Utah Press, Salt Lake City

Okumura M, Araujo AGM (2019) Archaeology, biology, and borrowing: A critical examination of Geometric Morphometrics in Archaeology. Journal of Archaeological Science 101:149-158. https://doi.org/10.1016/j.jas.2017.09.015

Olalde I, Mallick S, Patterson N, et al (2019) The genomic history of the Iberian Peninsula over the past 8000 years. Science 363:1230-1234. https://doi.org/10.1126/science.aav4040

Ollivier M, Tresset A, Frantz LAF, et al (2018) Dogs accompanied humans during the Neolithic expansion into Europe. Biol Lett 14:1-4. https://doi.org/10.1098/rsbl.2018.0286

Pardo-Gordó S, García-Puchol O, Diez-Castillo A, et al (2018) Taphonomic processes inconsistent with indigenous Mesolithic acculturation during the transition to the Neolithic in the Western Mediterranean. Quaternary International 483:136-147. https://doi.org/10.1016/j.quaint.2018.05.008

Pericot L (1945) La Cueva de la Cocina (Dos Aguas). Servicio de Investigación Prehistórica del Museo de Prehistoria de Valencia, Valencia

Perrin T (2001) Évolution du silex taillé dans le Néolithique haut-rhodanien autour de la stratigraphie du Gardon (Ambérieu-en-Bugey, Ain). Sciences de l’Homme et Société - Université de la Sorbonne

Perrin T, Allard P, Marchand G, et al (2010) The late Mesolithic of Western Europe: Origins and diffusion of blade and trapezes industries. In: Meso 2010-The 8th International Conference on the Mesolithic in Europe. HAL Id: hal-01813162, Santander

Perrin T, Binder D (2014) Le Mésolithique à trapèzes et la néolithisation de l'Europe sud-occidentale. In: Manen C, Perrin T, Guilaine J (eds) La transition néolithique en Méditerranée. Actes du colloque Transitions en Méditerranée, ou comment des chasseurs devinrent agriculteurs, Muséum de Toulouse, 14-15 avril 2011. Errance et Archives d'Ecologie Préhistorique, Paris, pp 271-281

Piras P, Colangelo P, Adams DC, et al (2010) The Gavialis-Tomistoma debate: the contribution of skull ontogenetic allometry and growth trajectories to the study of crocodylian relationships. Evolution \& Development 12:568-579. https://doi.org/10.1111/j.1525-142X.2010.00442.x

Plisson H, Dubreuil L, Guilbert R (2008) The functional significance of Sauveterrian microlithic assemblages: broadening the focus of investigation. In: Longo L, Skakun N (eds) Prehistoric Technology' 40 years later: Functional Studies and the Russian Legacy: Proceedings of the International Congress Verona (Italy), 20-23 April 2005. BAR International Series, Oxford, pp $147-156$

R Core Team (2017) R: A Language and Environment for Statistical Computing. Version 3.3.3. R 
Foundation for Statistical Computing, Vienna. URL https:/www.R-project.org/

Ragan K, Buchanan B (2018) Assessing Collector Bias: A Geometric Morphometric Analysis of a Collection of Isolated Clovis Points from the Midcontinent. Midcontinental Journal of Archaeology 43:91-111. https://doi.org/10.1080/01461109.2018.1426430

Reid G, Sidwell K (2002) Overlapping variables in botanic systematics. In: MacLeod N, Forey PL, Warren A (eds) Morphology, shape and phylogeny. Taylor \& Francis, London-New York, pp 53-66

Richter T (2007) A Comparative Use-Wear Analysis of late Epipalaeolithic (Natufian) chipped stone artefacts from the southern Levant. Levant 39:97-122. https://doi.org/10.1179/lev.2007.39.1.97

Rodríguez Alcalde Á, Alonso C, Velázquez J (1995) Fractales para la Arqueología: Un nuevo lenguaje. Trabajos de Prehistoria 52:13-24

Rohlf FJ, Archie JW (1984) A Comparison of Fourier Methods for the Description of Wing Shape in Mosquitoes (Diptera: Culicidae). Systematic Zoology 33:302-317. https://doi.org/10.2307/2413076

Rohlf JF, Marcus LF (1993) A revolution morphometrics. Trends in Ecology \& Evolution 8:129-132. https://doi.org/10.1016/0169-5347(93)90024-J

Shennan S (2018) The First Farmers of Europe: An Evolutionary Perspective. Cambridge University Press, Cambridge

Shott M (2015) Theory in Archaeology: Morphometric approaches to the study of fluted points. In: Goodale N, Andrefsky Jr. W (eds) Lithic Technological Systems and Evolutionary Theory. Cambridge University Press, New York, pp 48-60

Silva-Gago M, Fedato A, Rios-Garaizar J, Bruner E (2019) A preliminary survey on hand grip and handtool morphometrics in three different stone tools. Journal of Archaeological Science: Reports 23:567-573. https://doi.org/10.1016/j.jasrep.2018.11.012

Straus LG (2002) Selecting Small: Microlithic Musings for the Upper Paleolithic and Mesolithic Western Europe. In: Elston RG, Kuhn SL (eds) Thinking Small: Global Perspectives on Microlithization. American Anthropological Association, Arlington (Vi), pp 69-81

Thiele K (1993) The Holy Grail of the Perfect Character: the Cladistic Treatment of Morphometric Data. Cladistics 9:275-304. https://doi.org/10.1006/clad.1993.1020

Thulman DK (2012) Discriminating Paleoindian point types from Florida using landmark geometric morphometrics. Journal of Archaeological Science 39:1599-1607. https://doi.org/10.1016/j.jas.2012.01.004

Utrilla P, Montes L (2009) El Mesolítico Geométrico en la Península Ibérica. Departamento de Ciencias de la Antigüedad-Universidad de Zaragoza, Zaragoza

Vicent JM (1997) The Island Filter Model Revisited. In: Balmuth MS, Gilman A, Prados-Torreira L (eds) Encounters and Transformations. The Archaeology of Iberia in Transition. Sheffield Academic Press, Sheffield, pp 1-14

Vidal Encinas JM, Fernández Rodríguez C, Prada Marcos ME, Fuertes Prieto MN (2008) Los hombres mesolíticos de La Braña-Arintero (Valdelugueros, León): Un hallazgo funerario excepcional en la vertiente meridional de la Cordillera Cantábrica. Férvedes 5:153-164

Wiens JJ (2001) Character Analysis in Morphological Phylogenetics: Problems and Solutions. Syst Biol 50:689-699. https://doi.org/10.1080/106351501753328811

Wiley EO, Siegel-Causey D, Brooks DR, Funk VA (1991) The compleat cladist. A primer of phylogenetic procedures. University of Kansas Museum of Natural History, New York 
Zilhão J (1993) The Spread of Agro-Pastoral Economies across the Mediterranean Europe: A View from the Far West. Journal of Mediterranean Archaeology 6:5-63. https://doi.org/10.1558/jmea.v6i1.5

Zilhão J (2001) Radiocarbon evidence for maritime pioneer colonization at the origins of farming in west Mediterranean Europe. PNAS 98:14180-14185. https://doi.org/10.1073/pnas.241522898

Zilhão J (2014) Early prehistoric navigation in the Western Mediterranean: Implications for the Neolithic transition in Iberia and the Maghreb. Eurasian Prehistory Island Archaeology and the Origins of Seafaring in the Eastern Mediterranean 11(1-2):185-200

Zvelebil M (ed) (1986) Hunters in Transition: Mesolithic societies of temperate Eurasia and their transition into farming. Cambridge University Press, Melbourne

\section{CAPTIONS}

Fig. 1 Synthesized representation of the geometric microliths of the archaeological phases treated in the article, extracted from Cueva de la Cocina and Cova de l'Or. Chronological references are approximate

Fig. 2 Location of Cueva de la Cocina, and Cova de l'Or

Fig. 3 Boxplot showing the morphometric differences of geometric microliths when used as arrowpoints (AP) or sickles (SF). GX expresses the type of geometric, as defined by Javier Fortea

Fig. 4 Geometric over printed grid within the Geomeasure system. W_Lines, E_Lines, N_Lines and S_Lines refer to the domain and number of each group of lines. The program captures the amount of each line crossing the geometric and offers its length as an output. The numbers $[0,5 ; 5,10 ; 10,5 ; 5,0 ; 5,5]$ are UTM coordinates, used as standard points for faster georeferencing and scaling

Fig. 5 Outline for some of the geometric microliths used under a Geometric Morphometrics approach

Fig. 6 Different PCAs developed within the Geomeasure system. Fig. 6a shows comparison between length, area, width and maximum thickness, fig. $6 \mathrm{~b}$ refers to L-length and L-width lines and proximal and distal angles (Angle 1 and Angle 2), fig 6c analyses N, S, E and W lines - as they are shown in the text and in fig. 4 - and fig. 6d proximal and distal vertexes and bases

Fig. 7 Results of the Jaccard analysis. Fig. 7a shows an initial dendogram. Fig. 7b includes a heatmap of the values between phases

Fig. 8 PCA under a Geometric Morphometrics approach

Fig. 9 LDA under a Geometric Morphometrics approach

Fig. 10 Results of cross validation tests over LDA inputs show how many times the phase of the geometric has been correctly predicted according to its real phase and attending to the LDA analysis. The rows show the phase and the columns show the prediction. Darker colours show the highest number of correct predictions, whereas lighter colours show majority of mispredictions. As it can be seen, phase B2 is the most correctly predicted, thus offering a clear entity, whereas phase $\mathrm{C}$ has been erroneously predicted every iteration

Fig. 11 K-means values, showing that there are morphometrical patterns of clustering

Fig. 12 Diachronic tendencies of the means of each N-Line (only the first $10 \mathrm{~N}$-Lines are shown). The mean length of each line seems to decrease from the phase A to the phase B, whereas it stays steady during the phase $\mathrm{B}$, and raises abruptly with the first Neolithic phase 
